\title{
İletişimsel Etkisi Bağlamında Mezartaşı Fotoğrafları
}

\section{Gravestone Photos in The Context of Communicational Effect}

\author{
Ülhak Çimen ${ }^{\text {a,* }}$ \\ ${ }^{\text {a }}$ Dr. Öğr. Üyesi, Atatürk Üniversitesi İletişim Fakültesi, Radyo ve Televizyon Bölümü, 25240, Erzurum/Türkiye \\ ORCID: 0000-0002-7307-4874
}

\section{MAKALE BILLGISİ}

\section{Makale Geçmişi}

Başvuru tarihi: 02 Ocak 2020

Düzeltme tarihi: 20 Şubat 2020

Kabul tarihi: 05 Mart 2020

Anahtar Kelimeler:

Mezartaşı Fotoğrafları,

İletişim,

Ölüm,

Etki,

Fotoğrafik Geçirgenlik.

\section{ARTICLE INFO}

\section{Article history:}

Received 02 January 2020

Received in revised form 20 February 2020 Accepted 05 March 2020

\footnotetext{
Keywords:

Gravestone Photo,

Communication, Death,

Impact,

Photographic Permeability.
}

ÖZ

Ölen bir kişinin mezar yerinin belirlenmesi ve mezar yerinin yok olmaması amacıyla mezarların baş kısmına dikilen mezar taşları çeşitli anlamlar sunarlar. Mezar taşlarının üzerinde yer alan kimlik belirteçleri, semboller, yazılar ve görseller çeşitli mesajları insanlara aktarırlar. Mezar taşları üzerlerinde barındırdıkları kitabe ve tarih bakımından ele alındığında ise bunların tarihi belgeler olduğu kesindir. Ülkemizde mezar taşları ile ilgili çeşitli araştırmalar yapılmakta veya geçmiş yıllara ait çalışmalar yayımlanmaktadır. Bu araştırma ve çalışmalar genellikle geçmiş kültürlerin tarihi ve sanatı hakkında incelemeler sunan değerlendirmelerdir. Ancak güncel mezartaşı örnekleri de incelemeye alınması gereken önemli kültürel ve iletișimsel öğelerdir. Mezar taşlarına eklemlenen fotoğraflarla elde edilen mezartaşı fotoğraflarının insanlar üzerinde iletişimsel bir etki oluşturduğu düşünülmektedir. Bu çalışma mezartaşı fotoğraflarını iletişimsel yönüyle ele almaya çalışmıştır.

\section{A B S T R A C T}

Gravestones planted in the head of graves represent various special meanings to define the grave place for the people and also not to lose it. Identity indicators, symbols, writings and images on the gravestones transfer various messages to the people. It is a certain fact that these are historical documents when they are considered in terms of epitaph and history they contain. In our country, various researches on gravestones have been done and studies in the last years have been published. These researches and studies are generally evaluations presenting researches about the history and art of past cultures. However, current gravestones samples are significant cultural and communicational items that have to be studied. It is certain that gravestone photos that were made up by adding photos will have communicational effects on people. This study tried to discuss gravestone photos in terms of the communicational aspect.

\section{Giriş}

Fotoğraf ve ölüm arasında ne türden bir ilişkinin olduğu merak edilen konulardandır. Fotoğraf ölüm ilişkisi son 30 yıldır Avrupa'da yapılan çalışmaların önemlilerindendir. $\mathrm{Bu}$ çalışmaların bir kısmı hastaların, yaşlıların ve ölülerin fotoğraflarının çekilmesini içerimleyen klasik fotoğraf örnekleriyle ilişkiliyken bir kısmı da fotoğrafın teknik ve biçimsel yönünden koparak tamamen anlama yoğunlaşan çalışmalardır. Anlama yönelik çalıșmalar fotoğrafa bakan insanların ölen kişiyle dondurulmuş/sabitleştirilmiş görüntüler aracılığıyla etkili bir şekilde iletişim kurduklarını ve geleceğe yönelik bir akışı yani ölümü hatırladıklarını incelemektedir. Fotoğrafın ölümle ilişkisi diğer anlam belirleyen fotoğrafçılık türlerinin hepsinden daha önemli görülmektedir (Rosengarten, 2015:600-601). Fotoğraf ile ölüm arasındaki anlam ilişkisi mezartaşı fotoğraflarıyla daha etkili bir hal almaktadır.

İnsanlar mezar ziyaretlerinde normalden farklı bir ruh hali yaşarlar. Öncelikle bu ziyaretlerde akla gelen ölümün mutlak kaçınılmaz olduğudur. Ziyaret edilen mezar tanıdık bir kişinin mezarıysa ölmüş olan kişinin ismine, doğum/ölüm tarihine ve varsa çeşitli yazılara odaklanılmaktadır.

\footnotetext{
* Sorumlu yazar/Corresponding author.

e-posta: ulhakcimen@gmail.com
} 
Muhakkak ki bu odaklanma insana ölümü hatırlatmakta ve farklı bir iletişim durumuna geçilmektedir. Ancak mezartaşının üstünde ölen kişinin ismi, doğum/ölüm tarihi ve çeşitli yazıların haricinde bir de fotoğrafı mevcutsa fotoğrafa bakarak kurulan ilişki bütün iletişim biçimlerinden daha etkili olabilmektedir. Bu türden bir iletişim hem mutlak ölümü akla getirmekte hem de ziyaret esnasında fotoğraf aracılığıyla ölen kişiyle iletişim kurulmaktadır.

Her ne kadar ertelenmeye çalışılsa da ölümün mutlak kaçınılmazlığının bir gün herkesi bulacağı kabul edilmektedir. Barthes herkesin nihai kertede ölümle buluşacağı gerçeğini endoxical death söylemiyle açıklamaktadır (Barthes, 1982:187). Fotoğraf; ölüm bilincine aracılık eden bir bağlantı (Barthes, 2016:80), gerçekliğin sessiz bir formu, hareketsiz imaja bilinçsel yaklaşım ve sembolik bir ölüm olarak görülmektedir (Metz, 1990: 155-164). Fotoğrafın doğasında ölüm vardır. Barthes fotoğraf ve ölüm ilişkisini eidos kavramıyla açıklamaktadır (Barthes, 2016:27). Eidos nosyonu ölüm ve insan ilişkisinde ölümün insanlardan ayrı olmadığını göstermek için kullanılmıştır.

Fotoğrafin yaşamsal bilgiler sunması Barthes tarafindan Biographeme kavramıyla ifade edilmiştir (Palalı, 2017:2931). Dilimize biyogram olarak geçen bu kelime bir kişinin hayatındaki önemli tarihleri, olayları ve evreleri anlatan kısa bir hayat hikâyesidir. Biyogramlara mezartaşı fotoğraflarında da rastlanılmaktadır. Mezartaşı biyogramları ölen kişinin adını, soyadını, doğum ve ölüm tarihlerini yani yaşama dair bilgilerini sunan tarihi vesikalardır. Mezar taşlarında biyogramın tamamlayıcı unsurunun fotoğraf olduğu söylenebilir. Fotoğraf bir kişinin gerçekten yaşamış olduğuna tanıklık eden ve bunu görsel bir imajla tamamlayan etkileyici bir araçtır. Mezartaşındaki fotoğraf temsil ettiği kişiyi onaylayan tarihi bir kanıt ve kesin olarak yaşanmışlık belgesidir. Barthes bu durumu yaşamış olmanın sertifikası olarak adlandirmaktadır (Barthes, 2016:104).

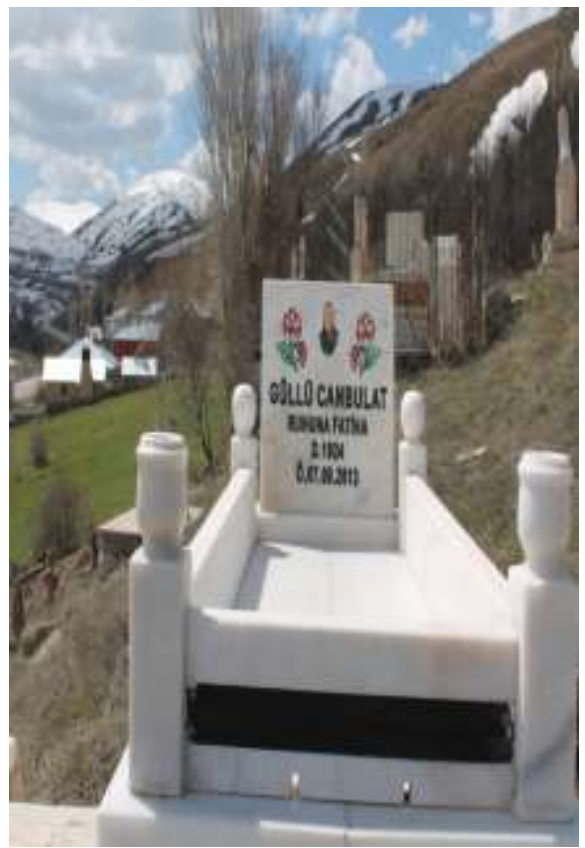

Fotoğrafla Desteklenmiş Biyogram Mezartaşı Örneği(Erzincan İli Refahiye İlçesi Mezarlı̆̆ 1 )
Fotoğrafik görme kavramı fotoğrafa bakan kişinin fotoğrafin içerisinde yer alan kişiyi tam olarak görmesi, algılaması ve iletişime geçmesi anlamına gelmektedir. $\mathrm{Bu}$ durum fotoğrafta gösterilen her şeyin görmeye müsaade edecek şekilde şeffaf kılınması anlamı taşımamaktadır. Fotoğrafik şeffaflık, fotoğrafta yer alan her şeyin mahremiyetinin yok sayılarak gösterilmesiyle değil fotoğrafa bakan kişinin bütün engelleri düşünsel olarak aşıp fotoğraftaki kişiyle duygusal bağlamda iletişim kurmasıyla kıymetli hale gelmektedir. Fotoğraf hayal etmeyi tetiklemeli, imgeyi görmeyle alakalı engelleri kaldırmaya ikna etmeli ve böylelikle şeffaflık kavramı değer kazanmalıdır (Değirmenci, 2016:130). İnsanlar bazı fotoğraflarla karşılaştıklarında ya onu bütünüyle kabul etmekte veya reddetmekte ya da fotoğrafin eksik kalan kısmını kendi imgeleriyle tamamlamaktadır (Berger, 2017: 27). İmgenin sessiz bir imaj olan fotoğraftan tayflanması iletişimin etkisini azaltmamakta aksine artırmaktadır. İmgenin etkisini artırması için fotoğrafta her şeyin gösterilmesine gerek yoktur, imgenin müdahalelerden bağımsız olmaya ihtiyacı vardır. Mezartaşı fotoğrafları yönlendirmeleri aşıp geçen ve imgenin etkisini doğrudan gösterdiği fotoğraflardır.

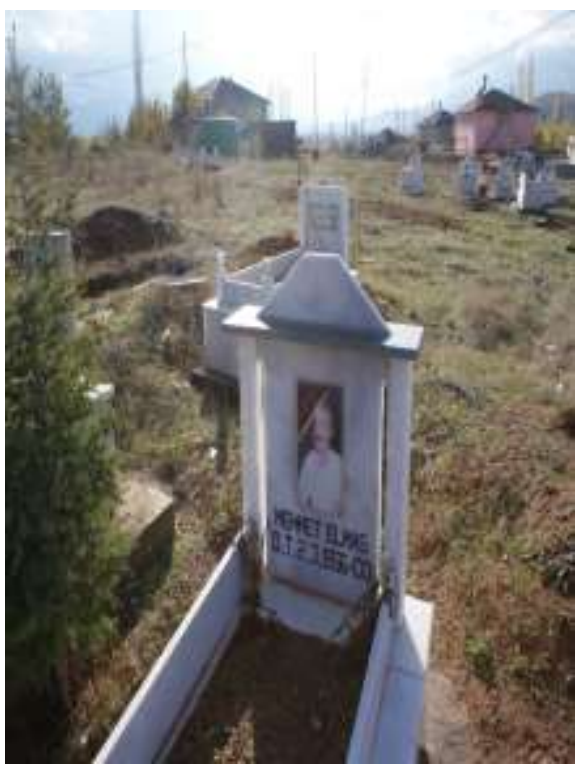

Fotoğrafik Görmeye Müsait Mezartaşı Fotoğrafı Örneği (Malatya İli Doğanşehir İlçesi Mezarlığı)

Tanıdığımız insanların mezartaşı fotoğraflarına baktığımızda ürpeririz. Çünkü fotoğrafta görünen kişi sadece o anı temsil etmemekte, yaşanmışlığın toplam bütününü imgelemeye imkân sunmaktadır. Bu fotoğraflar insanın yaşamını sorgulandığı ve yaşamına yönelik değerlendirmeler yaptığı etki gücü oldukça fazla olan fotoğraflardır. Mezartaşı fotoğrafları hem ölen kişiyle iletişime olanak sağlaması hem de nihai aşamada ölümün insanları bulacağını göstermesi açısından önemlidir. Mezartaşı fotoğrafının bilinen biri olması iletişimsel etkiyi güçlendirmekte ve ölen kişi geçici olarak diriltmektedir (Barthes, 2016). Bu dirilmenin süresi yakınlık derecesiyle doğru orantılidır. 


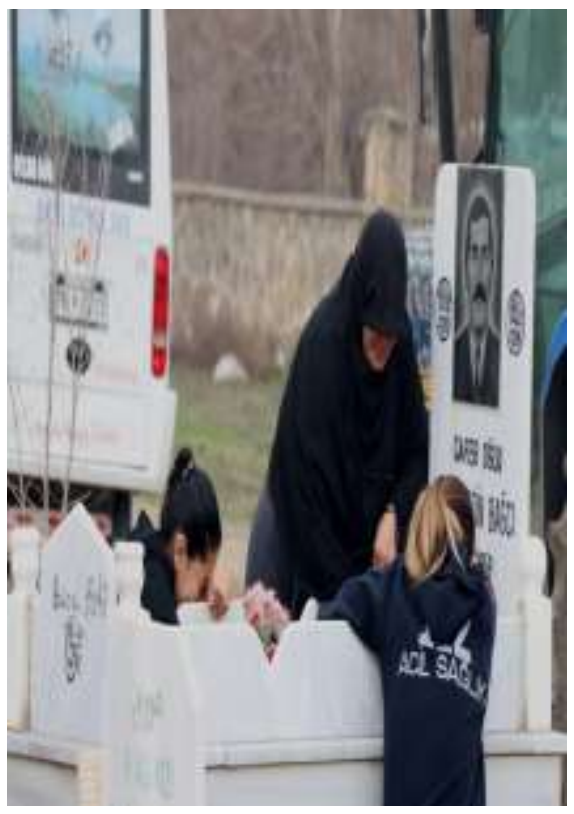

Tanınan Birinin Mezar Ziyaretinde İletişimsel Etkiyi Artıran Fotoğraf Örneği (Iğdır İli, Aralık İlçesi Mezarlığı)

\section{2. Çalışmanın Önemi ve Amacı}

Çalışma mezar taşlarına eklemlenen fotoğraflarla ortaya çıkan mezartaşı fotoğraflarının ölen kişi ile mezartaşına bakan kişi arasında etkili bir iletişime olanak sağladığını göstermesi açısından önemli görülmektedir. Yine çalışma şimdiye kadar mezartaşları konusunda yapılan çalışmalar içerisinde mezartaşı fotoğraflarını konu alan ilk ve güncel çalışmalardan birisi olduğu iddiasıyla önemlidir.

Çalışma mezartaşı fotoğrafları konusundaki tartışmaların(dinsel açıdan caiz olup olmadığı, farklı inançları çağrıştırdığı, belirli toplumlara özgü olduğu vb) uzağında durmaktadır. Amaç, fotoğrafın insanlar üzerindeki en etkili kitle iletişim aracı olduğu gerçeğini göz önüne alarak mezartaşı fotoğraflarının da bu etkiye sahip olabildiğini göstermektir.

\section{1. Çalışmanın Tekniği:}

Çalışmamızda literatür taraması yapılarak mezartaşı fotoğraflarının etkisi iletişimsel bağlamda ele alınmıştır. Ayrıca mezartaşı fotoğraflarını gösteren görseller çalışmamızda kullanılmıştır.

\subsection{Kavramsal Çerçeve:}

Çalışmamızın kavramsal çerçevesini aura, studium ve punctum kavramları oluşturmaktadır.

\subsubsection{Aura:}

Aura, Walter Benjamin'in fotoğraf analizlerinde kullandığı bir kavramdir.

"O halde aura nedir? Zaman ve mekanın alışılmadık dokusudur: bir uzaklı̆̆ın eşsiz biçimde ortaya çıkışıdır, ne kadar yakın olduğu fark etmez.. Ufuktaki bir dă̆ Sırasını ya da seyircisinin üzerine gölgesi düşen ağaç dalını gözümüzle takip ederek o dăgların ve ăgaç dalının aurasını soluruz", (Benjamin, 2015: 18; Leslie, 2019:114).

$\mathrm{Bu}$ anlamda aura fotoğrafa bakan kişinin fotoğraftan yayılan enerjiyi, hissi, ruhu ve etkiyi algılayabilmesidir. Mezartaşı fotoğraflarında ölen kişiyle farklı bir iletişim kurulduğunu kabul edersek bu fotoğrafların aurasının insanlara temas ettiğini söyleyebiliriz.

\subsubsection{Studium ve Punctum:}

Studium ve punctum, Roland Barthes'in fotoğrafa bakan kişiler üzerinde fotoğrafın oluşturduğu etkiyi açıklamada kullandığı kavramlardır.

"Studium; insan için bir tat, genel, hevesli, ama tabii ki özel keskinliği olmayan bir tür kendini verme punctum; studiumu delen, sahneden yükselen, ok gibi dişarl firlayan ve bana saplanan şey, iz yara, ısırık, kesik ve küçük deliktir"'(Barthes, 2016: 39-40).

Mezarlık ziyaretlerinde mezartaşı fotoğraflarına bakan insanlarda genel bir ilgi, ahlaki değer yargiları ve akıl aracılığıyla studium etkisinin oluştuğunu söyleyebiliriz. Ancak tanıdık birinin mezartaşı fotoğrafina bakıldığında studiumu aşan, insanın içine etki eden, maziyi hatırlatan farklı etkiler oluşabilmektedir ki bu durumda punctum etkisi ortaya çıkabilmektedir. Baudrilard punctum etkisini; açıklanamayan, aktarılamayan fotoğrafa bakan kişi ile fotoğraftaki kişi arasındaki sır, içi yaralayan etki, yeniden ölüm ve küçük diriliş olarak tarif etmektedir.( Baudrillard, 2011: 37-67).

\section{Mutlak Etki Bağlamında Fotoğraf}

\subsection{Fotoğraf Ölüm İlişkisi}

Ölüm, insan hayatının en hüzünlü evresidir. Bu evre hayatın sona erdiğini kesin biçimde ispatlamasının yanı sıra bazı inançlara göre ise ebedi bir hayata geçişi temsil etmektedir. $\mathrm{Bu}$ geçişte ölüme ilişkin çeşitli etkinlikler yapılmaktadır. Ölüm etkinliklerinin bitiminde ölünün defnedildiği yer ve bu yerin yapısı çeşitli mesajlar sunmaktadır. Mezar, bark, kümbet, kurgan, oba, kereksür, kegür, türbe gibi isimlerle ifade ettiğimiz bu yapının en önemli medyumu mezar taşlarıdır. Mezar taşları yapı olarak genellikle Başlık ve Sembol, Serlevha, Kimlik, Dua, Tarih'ten oluşmaktadır (Berk, 2018:117). Mezar taşlarının insanlara çeşitli mesajlar aktaran araçlar olduğu düşünülmekte ve bu mesajların insanlar üzerinde mutlak etkilerinin olduğu iddia edilmektedir (Sili, 1996; 220). Mezar taşları üzerindeki yazıların; bitkisel, geometrik süslemelerin; insan heykellerinin; at, koç, geyik, keçi, boğa vb hayvan tasvirlerinin; kavuk, fes, tarikat tacları, sarık vb başlıkların hepsinin ayrı ayrı anlamı bulunduğu için bunları iletişimsel yönüyle de kıymete değer görmek gereklidir. Ülkemiz açısından ele alındığında İslamiyet öncesi ve İslamiyet sonrasında taşların insanları temsil eden silüet görünümünde olduğu ve mezar taşlarının her şekliyle ileti sunduğu düşünülmektedir(Arslan, 2017: 1936). Dolayısıyla mezar taşlarını sadece tarihsel, kültürel ve sanatsal bağlamda değil iletişimsel anlamda da ele almak gereklidir.

Fotoğrafı çeken kişi ile fotoğrafi çekilen şey çekim esnasında kısa süreliğine yok olmaları fotoğrafik ölüm kavramıla açıklanmaktadır (Scruton, 2018: 169-198). Baudrillard, kendilerine yöneltilen fotoğraf makinesine teslim olarak ellerini yukarıya kaldıran çocukların görüntüsünü ölüme hazır olmayla yorumlamaktadır (Baudrillard, 2016:154). Zaten İngilizce shoot fiilinin hem fotoğraf çekmek hem de silahla ateş etmek anlamlarına gelmesi fotoğrafın ölümle yakın ilişkide olduğunu göstermektedir (Price, 2014:2) Fotoğrafi çekilen kişi poz verme durumuna uygun davranış değişikliği yaratmaktadır. $\mathrm{Bu}$ durum vücudun aktif 
dönüşümüdür ki bu durumda fotoğrafa göre bedenin kendi gerçekliğini kaybetmesi yani ölümü gerçekleşmektedir (Barthes, 2016:23). Fotoğrafik ölümde kişinin başka birine dönüşmesi, bilincin bedenden uzaklaşması durumu ortaya çıkmaktadır. Deklanşöre basma anı hem bir ölümü hem de mutlak ölümsüzlüğü bir araya getirmektedir (Ökten, 2011: 47). Baudrillard, özne ile nesnenin deklanşöre basıldığı anda bir araya gelmesi ve dünyanın bir süreliğine durmasını saf ölüm olarak ifade etmektedir(Baudrillard, 2012: 24-25). Bu saf ölüm sonrasında öznenin nesneyi algılayabilecek imgelemi ve duygulanım alanı yeniden devreye girmektedir.

\subsection{Fotoğrafın Zamansal Yönü}

Fotoğraf zamana ve mekâna gönderme yapar. Lakin fotoğrafın asıl gönderme yaptığı şey zamandır. Zamana gönderme yapan- Barthes'in daha doğru söylemiyle ölümü hatırlatan- fotoğraflar deli fotoğraflardır (Barthes, 2016,139). Fotoğraf makinesi zamana ilişkin yaşanmışlığ göstermekte oldukça başarılıdır. Fotoğraf sadece o anı yaşatmasının ötesinde geçmişe, şimdiye ve aynı zamanda geleceğe de gönderme yapmaktadır. Zamanı durduran fotoğrafın yaptığı şey iki boyutludur hem zamanı öldürmek hem de ölen zamanı geri çağırmaktır (Ökten, 2013:105). Ölüme karşı bir duruş gösteren fotoğraf ölümsüz kılmayı başarmada ve ölen biriyle iletişim kurmada oldukça başarılı bir araçtır. Fotoğrafta fotoğraf çekilen kişinin ölümsüz hale getirildiği bir zaman süreci; yok olamamanın tarihe sunduğu bir kanıt; geçmiş ve şimdi arasındaki bir köprü durumu vardır (Ökten, 2011:105). Var olmaya kanıt gösterilen fotoğrafta görülmesi gereken asıl noktalardan birisi de yok olmanın imkânsızlığıdır.

Belirli bir zaman dilimi içerisinde yaşanmışlığın kanıtı olan fotoğraf zamanla oyun oynayabilmektir. Dolayısıyla ölmüş olan bir kişi fotoğrafi sayesinde ölümsüzleştirilebilmekte, yaşamış olmasının kanıtı gösterilebilmekte ve sürekli yenilenen güncel şimdiye etkide bulunabilmektedir. Ölen birinin mutlak anlamda unutulması mümkün olamamaktadır. Roland Barthes bir zamanlar yaşamış olmanın mutlak ispatı anlamında bu vardı kavramını karşılayan noema terimini kullanmıştır (Akt: Palalı, 2017:31). Fotoğraf ölümü durdurmanın ve yok oluşun önüne geçmenin etkili bir yolu olarak gösterilmektedir(Ökten, 2013:106). Ölen birinin mezartaşı fotoğrafı ölümün bir anlığına durması ve ölen kişiyle iletişime geçmenin bir medyumudur. Gerçekliğin bir zamanının dondurularak gösterildiği fotoğraf ölümle yakın ilişkili, bakan kişinin duygu ve düşüncelerinde etki uyandıran bir zaman dondurucusudur. Mezartaşı fotoğrafina bakan izleyici fotoğrafa bakarak kendi yaşamını sorgulamakta, kendi ölümüne gönderme yapan bir anı yaşamaktadır.

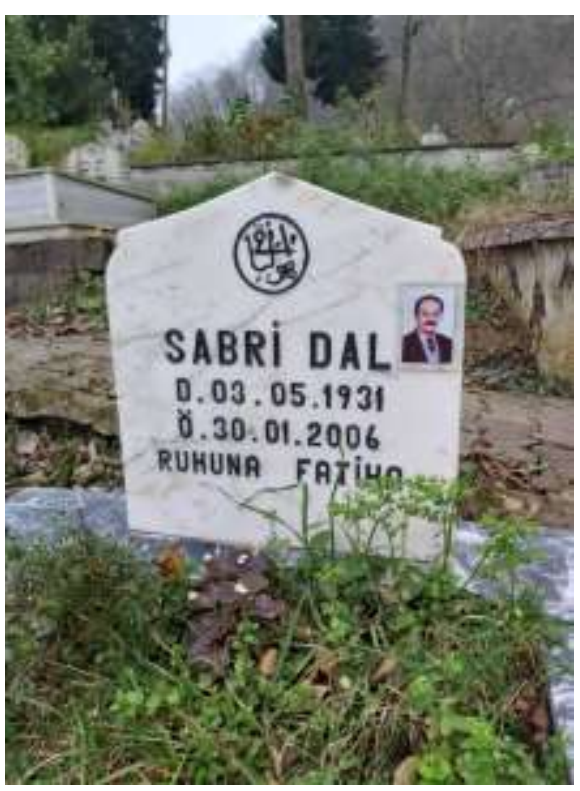

Belirli Bir Zamanda Yaşamış Olmanın Kanıtı Niteliğindeki Mezartaşı Fotoğrafi Örneği (Giresun İli, Kayadibi Mahallesi Mezarlığ 1 )

\section{3. İmgeye Etki Eden Fotoğraf}

Barthes annesinin ölümünden sonra annesiyle iletişim kurabileceği fotoğrafları ararken Kış Bahçesi Fotoğrafi'na denk gelir (Fotoğrafa bu ismi kendisi vermiştir). Bu fotoğraf kendisinden muazzam bir etki - yani punctum-oluşturur. Fotoğraftaki tayfın sadece kendisinde muazzam bir duygulanım oluşturduğunu düşündüğü için fotoğrafi kimseyle paylaşmaz ve çoğaltmaz. Barthes fotoğrafa baktığında ölümün hem er geç kendisini bulacağını hem de fotoğrafla birlikte ölümün imkânsızlığını anlar. Bu fotoğraf ölümün incelendiği, yansıtıldığı ve içselleștirildiği bir imajdır. Barthes, bu fotoğrafta fotoğraf ile fotoğrafa bakan kişi arasında gerçekleşen üst iletişimin gerçekleşebilmesi için ortak paydaların gerekliliğini vurgular (Barthes; 2016: 79-92). Mezartaşı fotoğraflarına bakan kişide duygulanım alanının gelişebilmesi için mutlak anlamda ortak payda gerekliliğinin olduğu söylenebilir. Çünkü kişi üzerindeki üst etki, tanıdık ve bildik olunması durumunda gerçekleşir. Genel ilgi, ahlaki ve politik kültür ve akıl ile gerçekleşen iletişim studiumu; studiumu delen geçen ve acı veren iletişim ise punctumu açıklamaktadır (Barthes, 2016: 40-41). Punctum barındıran mezartaşı fotoğrafları insanı yalnızlaştırmakta, acı vermekte ve ölüme karşı yetersiz bırakmaktadır.

Roland Barthes fotoğrafı gerçekliğin temsili olmasından ziyade duygulanım yaratan iletişim alanı olarak görmektedir. Fotoğrafı kendi başına kodsuz bir mesaj olarak gören düşünür fotoğrafa bakan kişinin kendi imgesine göre fotoğrafı değerlendirdiğini, dolayısıyla fotoğrafların daha duygusal, görünür ve önemli hale geldiğini iddia etmektedir (Barthes, 1982: 17). Fotoğraf, insanlara geçmişi sunan ve ölümü hatırlatan bir araçtır (Değirmenci, 2016: 226). Ölen birinin fotoğrafına baktığımızda ortaya çıkan punctum etkisi yönlendirilmelerden bağımsız biçimde kendiliğinden oluşan yaralayıcı bir etkiye sahip olabilmektedir.

Aynı şekilde Marcel Proust'un istemdışı bellek kavramı da ölen birinin fotoğrafına bakıldığında ortaya çıkan imgenin bağımsız durumunu ifade etmek için kullanılmaktadır. İstemdışı bellekte temel olan şey ölen kişiyle fotoğraf 
arasındaki benzerlik ya da özdeşlik değil içselleştirme durumudur. Punctum ve istemdışı bellek kavramları kişi ile gördüğü fotoğraf arasındaki özel ilişkiye gönderme yapmaktadır. Bu anlamda fotoğraf, görme alanını aşan ve ölen kişiyle fotoğrafa bakan kişi arasında izah edilmeyen bir iletişime imkân sağlayan, Walter Benjamin'in söylemiyle "zihnin eriştiği sinırların ötesini zorlayan ve yaşamışlı̆̆ından şüphe duyulmayan”(Benjamin,1969: 214) özel bir etki durumudur. Fotoğrafta görülen kişi ile ilgili bir bilgiye sahip olmadığımızda veya kişiyi tanımadığımızda mutlak etkiden bahsedebilmek mümkün değildir. Ölen kişiyle yaşadığı süredeki ortak yaşanmışlıklar mezartaşı fotoğrafinın etkisinin artırılmasına sebep olabilmektedir.

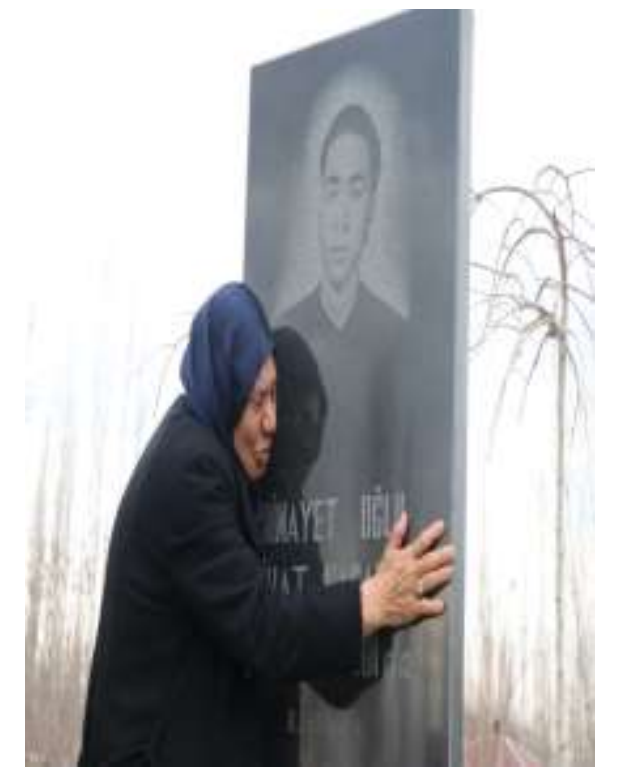

Bakan Kişide Punctum ve İstemdışı Bellek Etkisi Oluşturabilecek Fotoğraf Örneği(Iğdır İli Merkez Azeri Mezarlığı)

Fotoğraf ve fotoğrafa bakan kişi arasındaki iletişim benzerlik ilişkisinden ziyade içe işleyen genetik özelliklerle bağlantılı olabilir (Palalı, 2017, 26). Bazı genetik yüz özellikleri bireysel ruhun yansımasının haricinde bir ailenin genelini yansitabilmektedir. Barthes'e göre:

“Fotoğrafbazen gerçek bir yüzde(ya da aynadaki bir yüzde) göremediğimiz bir şeyi görünür kılar: genetik özellik, insanın kendisinin, ya da herhangi bir atadan gelen bir akrabasının parçası...Fotoğraf bedeni küçük parçalara bölmek koşuluyla küçük bir hakikat sunar. Ancak bu hakikat her zaman indirgenemez kalan bireyin hakikati değildir, soyun hakikatidir"'(Barthes, 2016:122).

\section{Mezartaşı Fotoğraflarının İletişimsel Yönü}

\subsection{Mezartaşı Fotoğraflarının Etki Gücü}

İlk dönemlerde fotoğraflar, ölülerin anılarının mezarlıktan aile oturma odasına taşınmasına yardımcı olmuştu (Linkman, 2011:207). Ancak gelişen teknolojik imkânlar fotoğrafların mezar taşlarına işlenmesine de olanak sağlamıştır. Böylelikle iletişim mekânsal farklılıklardan bağımsız hale gelmiş ve imge daha etkili biçimde oluşmaya başlamıştır. Bu türden bir imge duygulara dokunarak bilinç üzerinde mutlak farkındalık yaratabilmektedir. İmge, yönlendirme sonucunda ortaya çıkan şey değil; müdahalelerden bağımsız olarak kendi başına oluşan ve fotoğrafın içeriğini anlamlı kılan şeydir. Mezartaşı fotoğraflarında fotoğraf, imgeleme müdahale etmemek için ortadan kaybolmaktadır. Bu durum Jean Paul Sartre'nin Pierre Imgesi'ne benzemektedir. Sartre bir resim örneğinin Pierre'i gösterebilmek için kendisini yok ettiğini, kaybolduğunu ve bu durumun yansitıcı bilinç örneği olduğunu söylemiştir(Sartre, 2010: 24).

Studium kültürel ilgi alanını ifade ederken punctum, studiumu delen geçen ve insan üzerinde mutlak etki uyandıran şeydir. Punctumun insanı delen geçen yanı zamana gönderme yapmasıdır. Barthes fotoğraf görüntüsünün çoğalmasıyla birlikte punctumun belirsiz hale geldiğini zamana gönderme yapan fotoğraflarda ise punctumun daha belirgin olduğunu iddia eder (Barthes, 2016: 133). Zamana gönderme yapan fotoğrafların en önemlisi ölen kişilerin fotoğraflarıdır. Punctum etkisi fotoğrafin kendisinden değil fotoğrafa bakan kişiden kaynaklanmaktadır. Dolayısıyla punctumun düşünceyle, imgeyle, hayal kurmayla yakın ilişkisi bulunmaktadır. Mezartaşı fotoğraflarında punctum etkisinin genleşme gücü vardır. Yani mezartaşı fotoğrafındaki herhangi bir ayrıntı genleşerek bütün fotoğrafı doldurabilmektedir(Barthes, 2016: 61). Bu ayrıntının mezartaşı fotoğrafına bakan kişi üzerinde farklı bir iletişim etkisi; delip geçen bir niteliği olabilmektedir ki bu delip geçme punctum kavramını hatırlatmaktadır.

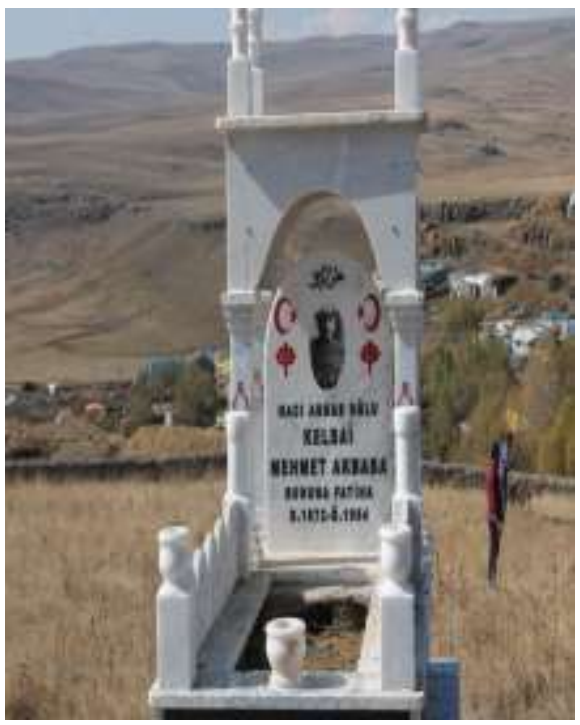

Ölen Kişiyi Tanımayan Biri Üzerinde Studium Etkisi Oluşturabilecek Fotoğraf Örneği (Kars İli, Akyaka İlçesi Mezarlı̆̆ı)

Bir görüntünün yaymış olduğu enerji Barthes tarafindan tayf kavramiyla, Benjamin tarafindan ise aura kavramlarıyla ifade edilmektedir. Tayf, Barthes'e göre en fazla fotoğrafik görüntüde ortaya çıkmaktadır. Özellikle ölen kişilerin fotoğraflarında tayf ölen kişinin kısa süreliğine dirilmesine aracılık etmektedir (Barthes, 2016:21). Küçük diriliş denilen bu geri dönüşte bilincin kısa süreliğine durması, duygulanım alanının dünyevi zamanı aşan bir hareketsizliği gerçekleşmektedir. Mezartaşlarındaki fotoğraf görüntüsü ölen kişinin mevcudiyeti varoluş ile ilgili mutlak bir kesinlik sunar. Fotoğraftaki kişi yaşamış olmanın bir ispatı geçmiş gerçekliğin bir yayılışı, akışı, sızışıdır (Palalı, 2017: 27). Bu akışta fotoğrafa bakan kişinin ölümü, fotoğrafta görülen kişinin ise dirilişi gerçekleşmektedir.

\subsection{Kişinin Ölmesi-Ölünün Dirilmesi}


Ölmüs birinin fotoğrafına bakan insanların hissettiklerinin din veya ritüelden farklı bir iletișim biçimi olduğunu kabul etmek gerekir (Palalı, 2017:13). Ölmüşlerin yaşama dönüşünü ifade eden eidolon kavramı mezartaşı fotoğrafçılığıyla yakinen ilişkilidir (Palalı, 2017:33). Fotoğrafın belirli bir yüzey üzerindeki görünümü haricinde o görünümün yaymış olduğu bir tür izge vardır. Görüntüdeki ölmüş kişi bir nevi fotoğrafa bakan kişi tarafından dünyaya çağırılmaktadır.

Fotoğrafa bakan kişiler fotoğrafta görmüş oldukları kişi/nesne ile yaşanmışlıkları ve bağları referans alarak değer yargisı ve tutum oluştururlar (Meskin vd., 2018:95). Yani fotoğrafta görünen şey kişilerin algılarını aktif hale getirerek iletişimi başlatmaktadır. Fotoğrafın taşımış olduğu ve herkes tarafından görülen bilgi Meskin ve Cohen tarafından v-bilgi olarak tanımlanırken herkes tarafından görülenin haricinde fotoğrafın taşımış olduğu özel değer ve bakan için özel anlam ifade eden bilgi ise e-bilgi olarak tarif edilmektedir (Meskin vd., 2018:97). İnsanlar tanıdıkları kişilerin fotoğraflarına baktıklarında tanımadıklarına kıyasla fotoğraflardan daha fazla etkilenirler (Walton, 2018:29-67). $\mathrm{Bu}$ durum gayet doğaldır. Walton önceden tanıdığımız birisiyle fotoğraf aracılığıyla temasımız gerçekleştiğinde o kişiyi kurgusal olarak gördüğümüzü ya da onunla iletişimi başlattığımızı ve sürdürdüğümüzü belirtir (Freeland, 2018:81). Bu türden bir iletişim biçimi ölüm söz konusu olduğunda belirli bir süreliğine ölümsüzlüğü ve ölüyle iletişimi kuvvetli hale getirmektedir. Hatta Walton bu görüntülerin bulanık ya da belirsiz olması halinde bile iletişimin gerçekleştiğini iddia eder.

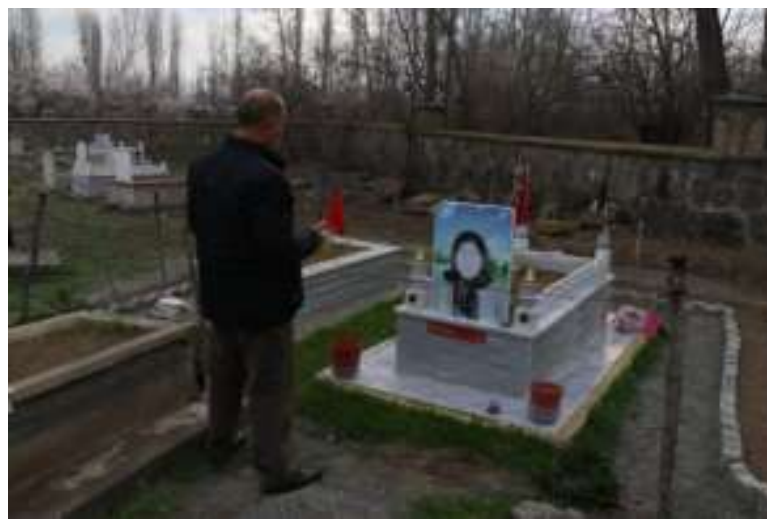

E-Bilgi Niteliği Taşıyabilecek Bir Fotoğraf Örneği

(Sivas İli İmranlı İlçesi)

Fotoğrafin geçirgen durumu bizi olmayan biriyle(yani yaşamayan birisiyle) gerçek iletişime sokar. Bu durum bütün iletişim biçimlerini aşan üst bir iletişim durumudur. $\mathrm{Bu}$ durumda iletişimi sağlayan şey benzerlikten ziyade yakınlık hissi ve çağrışım durumudur (Freeland, 2018:82). İletişimi güçlendiren çağrışım Carroll tarafından anıştırma kavramıla ifade edilmiştir (Carroll, 2018:299). Mezartaşı fotoğraflarında görüntünün insanlar üzerindeki asıl etkisi geçmişi hatırlatması değil, görünen kişinin bir zamanlar yaşamış olduğuna duyulan mutlak inanç ve bu inancın insanlar üzerindeki duygulanımlarıdır. Kişiler ölse bile kişinin aurası mezartaşında sonsuza kadar kalabilmektedir. Freeland bu durumu fotoğrafik geçirgenlik kavramıla açıklamaktadır. Mezar taşlarındaki fotoğraflar var kılmanın bir aracısı olarak iletişimin sürdürülmesinde etkili bir araç olarak kullanılmaktadır. Tanıdığı birinin mezartaşı fotoğrafına bakan kişi ile fotoğrafin yaymış olduğu 1 şı arasında gözle görülemeyen ancak mutlak anlamda aura taşıyan bir bağ vardır (Palalı, 2017:34). Kiși o mezar fotoğrafını gördüğü müddetçe bu bağ devam eder. Fotoğraftan yansıyan foton(1şık parçası) baktığımız kişinin bir yansımasıdır. Bu yansıma durumu süresince gerçekleşen iletişim yaşayan kişinin ölmesi ölen kişinin ise yaşama dönmesidir.

\subsection{Mezartaşı Fotoğrafları ve Porte İlişkisi}

Fotoğraf kullanılan mezar taşlarının hemen hemen tamamında portre fotoğrafları kullanılmaktadır. Çünkü portre fotoğrafları kimliği tanımlamada en etkili görüntü biçimleridir(Bate, 2013:105). Portre fotoğrafı kişiyi betimleyen, toplumsal kimliğini onaylayan, yaşanmışlığ ispat eden, benzerliğe anlam yükleyen, kimliği onaylayan ve ötekilerden ayırt eden fotoğraftır(Tagg, 1988: 37). İnsanların ruh halleri en iyi şekliyle portre fotoğraflarında ortaya çıkmaktadır. Çünkü portre fotoğrafları Barthes'e göre punctum etkisine en yakın olan fotoğraflardır. Kişilerin içsel özelliklerinin dışa yansımasının en iyi dışavurumsal görüntüleri portre fotoğraflarında ortaya çıkmaktadır(Sekula, 1996: 342-379). Genetik karakterlerin en iyi şekliyle portre fotoğraflarında analiz edilebildiği söylenebilir. Yüz, portre fotoğraflarının en önemli bileşenidir. Bir fotoğrafta anlamı belirleyen en önemli insan uzvu yüzdür(Bate, 2013: 115) Genetik kalıtımın en belirleyici olduğu yerin yüz olduğunu kabul edersek aidiyetin belirleniminde yüzün etkiyi oluşturan veya bağımsız bırakan en önemli temsil olduğunu onaylarız. John Berger, Jean Mohr'un portre fotoğrafi taslağını yazarken Mohr'un yüz ifadesinin karakterini dışa vurduğunu iddia etmektedir. (Berger, 2017:175-183). Portre fotoğrafi anlamın en saf biçimde ortaya çıktığı ve insanlara en doğru bilginin sunulduğu fotoğraflardır.

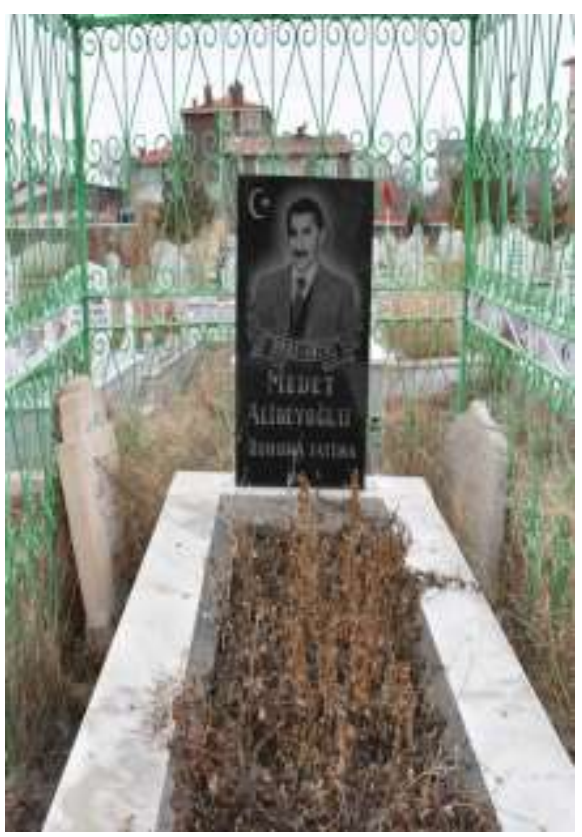

Portre Fotoğrafi Kullanılmış Bir Mezartaşı Örneği (Kars İli Merkez Mezarlığı)

Barthes portre fotoğraflarının kapalı kuvvetler alanı olduğunu iddia etmektedir (Barthes, 2016: 25). Studiumun bir maske ve punctumun da bu maskeyi ortadan kaldıran anlam olduğunu kabul edersek kapalı kuvvetler alanının studiumu aşıp punctuma etki ettiğini söyleyebiliriz. Mezartaşı fotoğraflarında maske anlamı meydana getiren saf 
gürültüdür. $\mathrm{Bu}$ saf gürültünün ortadan kalkması dışsal etmenlerle değil tamamen duygusal etkileşimlerle gerçekleşmektedir. Duygusal etkileşimlerde ölen kişinin ruhuna temas edilmekte ve aura hissedilebilmektedir. Bu his fotoğrafik görmeye olanak sağlayan şeydir. Fotoğrafik görme Mezartaşı fotoğrafına bakan birinin ruha temas etmesi ve o ruhla başkalarının anlayamayacağı bir iletişime geçmesi durumudur (Sontag, 2011:108-109).

\section{Sonuç}

Mezarların oluşturulma biçimleri o dönemin dini, sanatsal, toplumsal, ekonomik, kültürel ve iktisadi yapısını aktaran önemli yapılardır. Mezar taşları üzerindeki figürler, süslemeler, semboller, yazılar, motifler, resimler ve fotoğraflar ise ölen kiși hakkında bilgi sunan tarihi vesika niteliği taşırlar. $\mathrm{Bu}$ taşlar tarihin uzak ve yakın mazisinde, toplumsal değişim ve kültürlerarası iletişime bağlı olarak sürekli değişim gösteren kültürün önemli öğelerindendir (Çağlar,2018: 173). Mezartaşı fotoğrafları iletişimsel açıdan son derece önemli mesaj taşıyıcısı özelliğine sahiptir. Yapıldıkları döneme ait inanç, gelenek, sanat ve ekonomik duruma ilişkin birer mesaj taşıyıcısı olan mezar taşlarına eklemlenen fotoğrafların iletişimsel anlamdaki etkisini de göz önünde bulundurmak gereklidir. Çünkü mezar taşları tarih ve sanat bakımından ele alınmasının yanında güncel iletişim bağlamında da değerlendirmeye alınması gereken bir inceleme konusudur.

Fotoğrafın insanları etkileme gücünün diğer kitle iletişim araçlarına nazaran daha baskın olduğu kabul edilmektedir (Berger, 2017: 22-23). Susan Sontag'a göre fotoğrafların hareketli görüntülerden daha etkili olmasındaki sebep yaşanmışlığa ve imgeye müsaade tanıyan sabitleme durumudur (Akt. Ökten, 2011:108). Ölen birinin videolarının insanlar üzerinde mutlak etkilerinin olduğunu kabul edebiliriz. Ancak fotoğrafın etki durumu videoya nazaran daha baskın ve belirgindir. Çünkü fotoğraflar imgeye ve duygulanım alanına zamansal olarak müsaade etmektedir.

Fotoğraf; fotoğrafa bakan kişiyle fotoğrafta yer alan kişiyi aracısız iletişime sokan ve böylece görme ve duygulanım alanı kazandıran ikna aracıdır. Walton ölmüș olan tanıdıklarımızın fotoğraflarına baktığımızda simgesel olarak onları canlı hale getirebildiğimizi düşünmektedir (Walton, 1984: 246-277). İnsanlar tanıdıkları ölmüş birinin fotoğrafına baktıklarında fotoğrafta yer alan kişiyi aracısız bir şekilde görmekte ve kişiyle üst seviyede bir iletişim kurmaktalar (Maynard,1983: 160-161). Mezartaşı fotoğrafları da bakılan kişiyi simgesel olarak canlandırmaya, aracısız şekilde görmeye ve üst seviyede iletişim kurmaya olanak sağladıklarından duygulanım alanlarına daha belirgin etkide bulunabilmektedir.

Barthes'in punctum kavramında zamana ilişkin bir değer söz konusudur. Bu zaman ölümün mutlaklığının zamanını işaret etmektedir. Fotoğrafik yüzeydeki geçmişin görüntüsüyle gelecekteki mutlak yok oluşun(ölümün) aynı anda gözükmesi punctum etkisine yol açar. Bu durum geçmiş ve geleceğin fotoğraf düzleminde çakıştığı bir eşdeğerliği anlatır. Böyle bir eşdeğerlikte biçimden ziyade duygusal bir yeğinliğe aidiyet vardır (Palalı, 2017:66). Alexander Gardner tarafından 1865 yılında çekilmiş Lewis Payne portrelerinin punctum okuması ölümün zamanına ilişkin bir değer taşır ve bu değerin ifadesi mutlak anlamda herkes bir gün ölecektir. Neticesinde insanların zamana yenik düşükleri veya düşecekleri ölümü çağrıştıran punctum etkisi $b u$ ölmüsstür, bu ölecektir bağlamında ele alınmalıdır (Barthes, 2016: 113). Barthes'in interfuit terimi de mutlak anlamda yaşayan herkesin bir gün öleceğine gönderme yapmaktadır. Her fotoğraf mutlak ölümün kimseye farklı bir şans tanımadığ 1 bir gerçekliktir. Bu gerçekliğin en belirgin ve en etkili yaşandığ 1 yerin mezarlar ve bu etkiye olanak sağlayan en önemli aracında mezartaşı fotoğrafları olduğunu göz önünde bulundurmak gerekmektedir. Mezartaşı fotoğrafları fotoğrafın arka planındaki ölen kişiyi göstermeleri ve ölüyle iletişim kurmayı sağlamaları bağlamında önemli iletişim araçları olarak değerlendirilebilirler. Mezartaşı fotoğrafına bakan bir kişi ise hem ölmüş olan kişiyle üst seviyede bir iletişime geçtiği gibi mutlak anlamda ölümün kendisini de bulacağını bilmektedir.

Fotoğraf ölmüş olanı görünür kılması nedeniyle değerlidir. Fotoğrafın asıl temsil ettiği şey hatıraları yenilemesi değil bir zamanlar var olmanın yaşamanın mutlak tanıklığıdır. Mezartaşı fotoğrafları geçmişin yadigârı, yaşanmışlı̆̆ın ispatı, ölümün imkânsızlığıdır. Fotoğraftaki kişi ile kurulan iletişim ölüyü kısa süreliğine de olsa sembolik anlamda diri hale getirmektedir (Berger, 2017: 76). Bu durum mezartaş1 fotoğraflarının insan bilinciyle yakın ilişkisinin olduğunu ve mezartaşı fotoğraflarının belirlenmiş koddan bağımsız birer araç niteliği taşıdıklarını göstermektedir (Barthes, 1982:17).

Ölmüş bir insanın fotoğrafina veya mezartaşı fotoğrafina baktığımız zaman fotoğrafin çekildiği zaman bağlamına değil, ölümün mutlak anlamda bir zamanda herkesi bulacağı düşüncesine odaklanırız (Palalı, 2017:61). Kişi böylesi bir bakışta kendi ölümünü de düşünmeye başlar. Burada fotoğrafin ölümle dolayımsız ilişkisi söz konusudur. Zaten Barthes'in "fotoğraf saha kalıcı yüzeylere yapıştırılsa da daha ölümlüdür" (Barthes, 2016:111) cümlesinden anlaşılması gereken şey ölen birinin fotoğrafına her bakıldığında mutlak anlamda ölüm düşüncesinin zihnimizde yer edeceğidir.

\section{Kaynaklar}

Arslan, A.S.(2017). "Taşlar Konuşur”: Türk Mezar Taşlarının Biçim Dili. Uluslararası Türkçe Edebiyat Kültür Eğitim Dergisi Sayı: 6(3), 9231937.

Barthes, R. (2016). Camera Lucida Fotoğraf Üzerine Düşünceler. Reha Akçakaya(Çev.). İstanbul: Altıkırkbeş Yayın.

Barthes, R. (1982). Image, Music, Text. Stephen Heath(Tr.). London: Fontana Press.

Bate, D. (2013). Fotoğraf Anahtar Kavramlar. Bahar Şimşek(Çev.). Ankara: De Ki Basım Yayım.

Baudrillard, J.(2016). Kötülüğün Şeffaflı̆̆ı Aşırı Fenomenler Üzerine Bir Deneme. Iş1k Ergüden(Çev.). İstanbul:Ayrıntı Yayınları.

Baudrillard, J.(2012). Neden Her Şey Hala Yok Olup Gitmedi. Oğuz Adanır(Çev.). İstanbul: Boğaziçi Üniversitesi Yayınevi. 
Baudrillard, J.(2011). Tekil Nesneler Mimarlık Felsefe. Aziz Ufuk Kılıç(Çev.). İstanbul: Yapı Endüstri Merkezi Yayınları.

Benjamin, W. (1969). Illuminations. Harry Zohn(Tr.). Newyork: Shocken Books.

Berger, J.(2017). Bir Fotoğrafi Anlamak. Geoff Dyer(Haz. ve Sun.). Beril Eyüboğlu(Çev). İstanbul: Metis Yayıncilık.

Berk. O.(2018). 1.Uluslararası Türk-İslam Mezar Taşları Kongresi Bildiri Kitabı İçinde: Osmanlı Mezartaşı Kitâbelerinde Başlıklar ve Anlamlarl. M.Duranl, R.K. Haykıran, G. K.Demir(Ed.). (s.116-123). Aydın: Adnan Menderes Üniversitesi.

Carroll, N.(2018). Fotoğraf Felsefesi(Doğanın Kalemi Üzerine Denemeler) İçinde: Scott Walden(Der.). Film Ylldızlarlyla İlgili Sorun. Aylin Ünal, Hüseyin Yılmaz(Çev.). (s.293-311).İstanbul: Espas Sanat Kuram Yayınları.

Çağlar, İ.M.(2018).1.Uluslararası Türk-İslam Mezar Taşları Kongresi Bildiri Kitabı İçinde: Mezartaşlarının Göç ve İskan Tarihi Araştırmalarında Yardımcı Kaynak Olarak Kullanımı: Karkın ve Çobanisa Örneği. M.Duranl1, R.K.Haykıran, G.K. Demir(Ed.). (s.161-173). Aydın: Adan Menderes Üniversitesi.

Değirmenci K.(2016). Fotoğrafin Imgeleri Temsil, Gerçeklik ve Dijital Çağda Fotoğraf, İstanbul: Doğu Kitabevi.

Freeland, C. (2018). Fotoğraf Felsefesi(Doğanın Kalemi Üzerine Denemeler) İçinde: Scott Walden(Der.). Fotoğraflar ve İkonalar. Aylin Ünal, Hüseyin Yılmaz(Çev.). (s.69-91).İstanbul: Espas Sanat Kuram Yayınları.

Linkman A. (2011), Photography and Death, London: Reaktion Books.

Maynard, P.(1983), The Secular Icon: Photography and the Functions of Images, Journal of Aesthetics and Critism, 42(2), 155-169.

Meskin, A. , Cohen, J.(2018). Fotoğraf Felsefesi(Doğanın Kalemi Üzerine Denemeler) İçinde: Scott Walden(Der.). Kantt Olarak Fotoğraf, Aylin Ünal, Hüseyin Yılmaz(Çev.). (s.93-113). İstanbul: Espas Sanat Kuram Yayınları

Metz, C.(1990), The Critical Image in: Photography and Fetish, C. Squires(Ed.), (s.155-164). London: Lawrence \&Wishart.
Ökten, A.İ.(2011). Fotoğraf Yazılarl. Ankara: Alter Yayıncilik.

Ökten, A.İ. (2013). Fotoğrafin Eleştirel Gücü Fotoğraf Yazılarl-2. Ankara: Alter Yayınc1lık.

Sili, T. (1996). Taşların Dili, Bilig-2 Dergisi içinde, Yaz(1996).

Leslie, E.(2019). Walter Benjamin Fotoğraf Yazıları. Burcu Halaç, Tevfik Turan(Çev.). İstanbul: Kolektif Kitap.

Palalı, A.T.(2017). Kış Bahçesinden Fotoğrafa(Bir Roland Barthes Yolculuğu). İstanbul: Altıkırkbeşyayınları.

Price, M. (2014). Fotoğraf Çerçevedeki Gizem Ayşenaz Koş, Kubilay Koş(Çev.). İstanbul: Ayrıntı Yayınları.

Rosengarten, R. (2015). ' .. and death I think is no parenthesis': the aged, the ill and the dying in contemporary photographic practice, in Crtical Arts29(sup)1, December, 529-608

Sartre, J. P.(2010). The Imaginary: A Phenomenological Psychology of the Imagination, Jonathan Webber(Tr.), Newyork and London: Rotledge.

(Aynı eser: Çevrimiçi:https://epdf.pub/the-imaginary-aphenomenological-psychology-of-the imagination.html Erişim tarihi: 17.06.2019)

Scruton, R.(2018) Fotoğraf Felsefesi(Doğanın Kalemi Üzerine Denemeler) İçinde, Scott Walden(Der.). Fotogrraf ve Temsil, Aylin Ünal, Hüseyin Yılmaz(Çev.). (s.169-198). İstanbul: Espas Sanat Kuram Yayınları.

S. Allan(1996). The Contest of Meaning in: Richard Bolton(Ed.). The Body\&The Archive. London: MIT Press.

Sontag, S. (2011), Fotoğraf Üzerine, Osman Akınhay(Çev). İstanbul: Agora Kitaplığı.

Tagg, J.(1988). The Burden of Representation Essays on Photographies and Histories, Basingstoke: Palgrave Macmillan.

Walton, K. L.(2018), Fotoğraf Felsefesi(Doğanın Kalemi Üzerine Denemeler) İçinde: Scott Walden(Der.). Geçirgen Fotoğraflar: Fotoğrafik Gerçekliğin Doğast Üzerine. Aylin Ünal, Hüseyin Yllmaz(Çev.). (s.29-67). İstanbul: Espas Sanat Kuram Yayınları

Walton K.L.(1984), Transparent Pictures: On the Nature of Photographic Realism, in Critical Inquiry, 11(2), 246-277. 